\title{
PERANCANGAN SISTEM EVALUASI KINERJA DIREKTORAT PEMBERITAAN LPP-TVRI DENGAN PENDEKATAN BALANCED SCORECARD (BSC)
}

\author{
Deasy Indriani ${ }^{*}$, , Idqan Fahmi**), dan Ahmad Mukhlis Yusuf ${ }^{* * *}$ \\ *) Lembaga Penyiaran Publik Televisi Republik Indonesia (LPP TVRI) \\ Jl. Gerbang Pemuda No. 8, Jakarta 10270 \\ **) Sekolah Bisnis, Institut Pertanian Bogor \\ Jl. Raya Pajajaran, Bogor 16151 \\ ***) BINUS Business School \\ The Joseph Wibowo Center, Hang Lekir I No. 6, Senayan, Jakarta 10270
}

\begin{abstract}
The objectives of the research are to 1) formulate a BSC based performance model criteria in the Directorate Information LPP-TVRI, 2) derive the Directorate of Information LPPTVRI strategic components (vision and mission) into a strategic plan, objective and initiative, 3) develop a strategy map for the Directorate of Information LPP-TVRI, 4) define chosen factors in KPI as a performance criteria, , 5) conduct a simulation on the performance criteria plan in the Directorate of Information LPP-TVRI using BSC method. The method used in the research is Balanced Scorecard (BSC) for 4 perspectives; finance, consumer, internal business process, and growth and learning perspectives. The result is presented in a strategic plan, objective and initiative based on the BSC four perspectives. This becomes a measured output and can be evaluated by the management. The focus on the improvement in this perspective will show a significant improvement. The effort of the Information Directorate to increase the audience share as the responsibility in using public funds from APBN is carried out by specifying the KPI to be implemented. The evaluation plan simulation on the performance of the Directorate Information LPP-TVRI derived from BSC method and the flow of cause and effect relationship through Strategy map, resulting in the presence of a number of KPI that has to be implemented by the TVRI management.
\end{abstract}

Keywords: $\quad$ balanced scorecard key, key performance indicators, Strategy Map, public television

\begin{abstract}
ABSTRAK
Tujuan penelitian ini adalah 1) merumuskan model pengukuran kinerja berbasis BSC dilingkungan Direktorat Pemberitaan LPP-TVRI, 2) menurunkan komponen-komponen strategik (visi-misi) Direktorat Pemberitaan TVR kedalam rencana strategik, tujuan dan inisiatif strategik, 3) membentuk Strategy Map untuk Direktorat Pemberitaan TVRI, 4) menentukan faktor-faktor apakah yang akan dipilih menjadi KPI sebagai pengukuran kinerja dan 5) melakukan simulasi rancangan pengukuran kinerja Direktorat Pemeberitaan TVRI dengan metode BSC. Metode penelitian yang digunakana Balanced Scorecard (BSC) dengan empat perspektif; perspektif keuangan, perspektif pelanggan, perspektif proses bisnis internal dan perspektif pertumbuhan dan pembelajaran. Hasil penjabaran komponen strategik Direktorat Pemberitaan LPP-TVRI kedalam rencana strategis, tujuan dan inisiatif melalui empat perspektif BSC menghasilkan output dan outcome yang terukur, sekaligus bisa dievaluasi oleh jajaran top manajemen. Fokus perbaikan pada perspektif ini, akan memperlihatkan perbaikan yang signifikan. Upaya Direktorat Pemberitaan meningkatkan audience share sebagai bentuk pertanggungjawaban penggunaan dana publik lewat APBN, dilakukan dengan menentukan KPI yang harus dilaksanakan. Simulasi rancangan penilaian kinerja atas Direktorat Pemberitaan LPP-TVRI, yang diturunkan dari metode BSC dan membuat alur hubungan sebab akibat lewat Strategy Map, menghasilkan sejumlah KPI yang harus dijalankan oleh manajemen TVRI.
\end{abstract}

Kata kunci: balanced scorecardkey,key performance indicators, Strategy Map, televisi publik

\footnotetext{
${ }^{1}$ Alamat Korespondensi:

Email: deasy_tvri@yahoo.com
} 


\section{PENDAHULUAN}

Hasil survei AGB Nielsen memperlihatkan 96\% masyarakat Indonesia menonton televisi. Kenyataan ini menempatkan televisi sebagai media pilihan masyarakat. Menurut Armando (2011), Siaran televisi memiliki kekuatan untuk Memengaruhi budaya jauh lebih luas daripada media lainnya. Siaran televisi masuk ke ruang keluarga, bisa lebih dari 20 jam sehari dan dinikmati oleh siapapun tanpa peduli tingkat pendidikan dan usia.Konsekwensinya adalah siaran televisi bisa membangun atau merusak kebudayaan, karena para pelaku industri televisi justru memilih menyajikan materi yang tidak bermanfaat untuk masyarakat. Siaran televisi tanpa disadari telah mendorong lahirnya imperialisme budaya yang dikhawatirkan mampu mengikis identitas (budaya) bangsa (Mark, 2005).

Indonesia kini memiliki 230 stasiun penyiaran televisi, sebelas diantaranya adalah stasiun penyiaran nasional Sowardi dan Suharsono (2012). Salah satu diantara stasiun penyiaran adalah TVRI, yang diamanatkan dalam UU No. 32 tahun 2002 sebagai televisi publik. Televisi Publik dapat ditemukan di banyak negara, yang misi utamanya adalah pelayanan publik.Sejak era monopolistik siaran usai pada dekade akhir 1980-an, TVRI dihadapkan pada tantangan kompetisi global dan kehadiran televisi swasta. Selera pemirsa mengalami pergeseran dengan semakin bervariasinya program tayangan lembaga penyiaran swasta.Sebagai lembaga negara yang mendapatkan penganggaran dari negara, TVRI harus mengawal tugas menjadi penyeimbang dan menjadi tayangan alternatif, tanpa mengabaikan upaya pemenuhan kepentingan, selera dan keperluan pemirsa di seluruh nusantara.

Inggris memiliki British Broadcasting Corporation (BBC) yang merupakan perusahaan layanan penyiaran publik, yang pendanaannya berasal dari lisensi televisi, bisnis komersial hingga hibah dari pemerintah. $\mathrm{BBC}$ mengoperasikan $\mathrm{BBC}$ One dan $\mathrm{BBC}$ Two sebagai televisi pembawa bendera negara. Sementara Australian Broadcasting Corporation (ABC) adalah penyedia layanan siaran non komersial di Australia, yang sepenuhnya dibiayai oleh pemerintah.ABC memiliki tiga saluran penyiaran yang masing-masing terbagi dalam segmen berbeda. $\mathrm{ABC} 1$ saluran televisi utama menyiarkan berita, informasi, dokumenter, hingga drama. $\mathrm{ABC} 2$, siaran digital yang menayangkan program ulangan dari $\mathrm{ABC} 1 . \mathrm{ABC} 3$ hadir menyiarkan tayangan yang fokus pada segmen anak-anak. Korea memiliki Kyeongseong Broadcasting Corporation (KBS) yang merupakan perusahaan jaringan radio dan televisi terbesar. Berbeda dengan stasiun penyiaran publik lainnya di banyak negara, sebagian besar penghasilan KBS didapat dari iklan. Begitupun halnya dengan televisi publik di negara Singapura. MediaCorp adalah perusahaan media milik negara yang sahamnya 100\% dimiliki oleh Temasek Holdings milik kerajaan Singapura. MediaCorp mengoperasikan 7 saluran televisi di bawah naungan perusahaan induknya.

Jika dibandingkan TV Publik di berbagai negara, seperti BBC, NHK, dan KBS, audience share TVRI tertinggal jauh. Sebagai televisi Publik, TVRI harus berjuang meningkatkan jumlah pangsa penontonnya sehingga mencapai angka ideal 5-10\% dari total jumlah penduduk Indonesia. Data audience share yang dirilis AC. Nielsen per Juni 2013 (23 hingga 26 Juni) pada Gambar 1 memperlihatkan rendahnya jumlah pangsa penonton TVRI, hanya $1,1 \%$. Penulis tidak dapat memberikan data terbaru terkait audience share TVRI, disebabkan TVRI tidak lagi berlangganan AC. Nielsen karena pembintangan anggaran TVRI oleh DPR-RI di awal tahun 2014

Salah satu penelitian yang dilakukan oleh Hastings (2004) padaTV Publik BBC, menggaris bawahi bahwa nilai tambah didapat dengan memberikan prioritas pada perspektif pelanggan dengan menciptakan kehadiran tv publik yang memiliki tayangan berkualitas tanpa adanya tekanan politik. Sementara itu, Sales (2013) melakukan penelitian terhadap TV Publik lokal di Spanyol, yang tergabung dalam 70 chanel TV lokal. Upaya meningkatkan audience share dalam kerangka memperoleh pangsa iklan sebesar-besarnya, mampu mengefisienkan alokasi anggaran dari pemerintah daerah.

Rendahnya capaian pangsa penonton, menjadi pekerjaan rumah yang harus diselesaikan segera oleh jajaran manajemen dan pegawai TVRI. Rendahnya capaian audience share sekaligus memperlihatkan rendahnya kinerja institusi. Dalam praktiknya evaluasi atas kinerja manajemen yang disepakati antara manajemen dengan Dewan Pengawas tidak berjalan konsisten. Performa manajemen tidak pernah diukur dalam sebuah alat ukur yang standar berbasis hasil, begitupun halnya dengan karyawan, selama ini luput dari bentuk evaluasi dan pengawasan. 


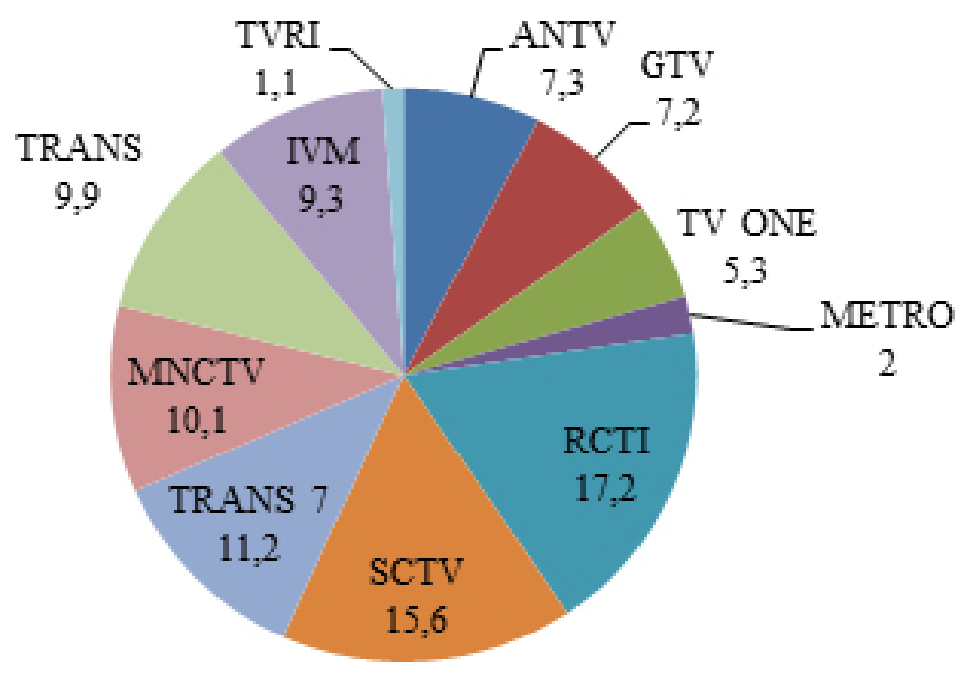

Gambar 1. Survei pangsa penonton minggu ke 26 tahun 2013 (AC Nielsen, 2013)

Sistem penilaian kinerja, key performance indicators (KPIs) dan evaluasi tidak pernah dimiliki dan dijalankan selama ini, diseluruh Direktorat LPP-TVRI. Salah satu pendekatan pengukuran kinerja yang ada saat ini adalah Balanced Scorecard (BSC). Pada awalnya BSC hanya digunakan pada organisasi profit.Tapi kini BSC juga banyak diterapkan oleh organisasi non-profit di banyak negara Penerapan BSC juga dilakukan pada rumah sakit-rumah sakit milik pemerintah Kompourus (2012).Mei dan Jiang (2013) dalam penelitiannya menemukan, pemerintah lokal China, menerapkan BSC pada pemerintahan sosialis dengan memperbaiki pelayanan publik.Sementara itu, Lang (2004) melakukan penelitian di Departemen Perhubungan Negara bagian Illinois.Hasilnya terlihat penerapan BSC mampu menurunkan angka kematian dan kecelakaan di jalan raya. Penelitian oleh Body (2008), Anthoula dan Alexandros (2011) memperlihatkan penerapan BSC membutuhkan koreksi pada perspektif pelanggan. Dengan demikian, tujuan penelitian ini adalah 1) merumuskan model pengukuran kinerja berbasis BSC dilingkungan Direktorat Pemberitaan LPP-TVRI, 2) menurunkan komponen-komponen strategik (visimisi) Direktorat Pemberitaan TVR kedalam rencana strategik, tujuan dan inisiatif strategik, 3) membentuk Strategy Map untuk Direktorat Pemberitaan TVRI, 4) menentukan faktor-faktor apakah yang akan dipilih menjadi KPI sebagai pengukuran kinerja dan melakukan simulasi rancangan pengukuran kinerja Direktorat Pemebritaan TVRI dengan metode BSC.
Lingkup penelitian hanya sebatas perencanaan dalam pengukuran kinerja organisasi dengan menggunakan BSC pada Direktorat Pemberitaan LPP-TVRI. Penelitian dibatasi hanya sampai menjabarkan visi dan misi organisasi, hingga perancangan pengukuran kinerja. UU Nomor 32 Tahun 2002 tentang Penyiaran dengan tegas menyebutkan bahwa penyelenggaraan penyiaran bertujuan "untuk memperkukuh integrasi nasional, terbinanya watak dan jati diri bangsa yang beriman dan bertakwa, mencerdaskan kehidupan bangsa, memajukan kesejahteraan umum, dalam rangka membangun masyarakat yang mandiri, demokratis, adil dan sejahtera, serta menumbuhkan industri penyiaran Indonesia". Amanat UU Penyiaran tersebut diterjemahkan kedalam Visi dan Misi TVRI yang relevan sehingga dalam ruang lingkup penelitian, penulis tidak lagi memasukkan Visi dan Misi TVRI sebagai salah satu objek penelitian.

\section{METODE PENELITIAN}

Penelitian dilaksanakan di LPP TVRI Divisi Pemberitaan. Penelitian dilakukan daribulan Meihingga Desember 2014. Pengambilan data dilakukan dengan Focus Group Discussion (FGD), Indepth Interview (wawancara mendalam) dan studi kepustakaan, serta laporan/tulisan. 
Jenis dan sumber data yang dikumpulkan adalah data primer dan data sekunder dalam bentuk kualitatif dan kuantitatif. Responden internal terdiri dari tujuh orang yang mencakup manajemen dan direksi LPP-TVRI. Seperti yang dituliskan dalam Tabel 2. Khusus untuk Direktur Program dan Berita pada saat dilaksanakannya FGD dalam posisi kosong dan dijabat sementara oleh Direktur Tekhnik. Proses FGD dilaksanakan satu kali dengan memberikan kuesioner tambahan sebagai alat bantu penyamaan perspesi.

Data sekunder berupa data keuangan diperoleh dari Laporan Tahunan 2013 dan 2014 LPP-TVRI. Sedangkan data pelatihan didapatkan dari hasil workshop Balaidiklat. Data pendukung seperti kebijakan manajemen saat ini diperoleh dari direksi dan manajemen..

Pengolahan data menggunakan metode pairwaise comparison. Perbandingan antar indikator horizontalvertikal dalam skala 1,2,3 dengan keterangan sebagai berikut:

Nilai 1 : indikator horizontal kurang penting dibanding indikator vertikal

Nilai 2 : Indikator horizontal sama penting dibandingkan indikator vertikal

Nilai 3 : Indikator horizontal lebih penting dibanding vertikal

Bobot setiap variabel diperoleh dengan menentukan nilai setiap variabel terhadap jumlah nilai keseluruhan variabel dengan menggunakan rumus sebagai berikut:

$$
\alpha_{i}=\frac{X_{i}}{\sum_{i=1}^{n} X_{i}}
$$

Keterangan:

$\mathrm{i}=1,2,3, \ldots . . \mathrm{n}$

$\alpha \mathrm{i}=$ bobot variabel ke- $\mathrm{i}$

$\mathrm{xi}=$ nilai variabel $\mathrm{ke}-\mathrm{i}$

$\mathrm{n}=$ jumlah variabel

Besaran kontribusi masing-masing indikator kinerja terhadap kinerja organisasi secara keseluruhan didapat dengan melakukan pengalian bobot masing-masing KPI dengan bobot perspektifnya. Untuk menghitung capaian kinerja KPI digunakan standar BSC yang diterapkan Kementrian Keuangan, melalui rumus capaian kinerja KPI menggunakan polarisasi data, maximize, minimize dan stabilize. Polarisasi maximize digunakan untuk membobot KPI dengan hasil realisasinya diatas target. Polarisasi minimize digunakan untuk membobot KPI yang hasil realisasinya diharapkan nilainya lebih kecil dari target. Sebaliknya, polarisasi stabilize digunakan unutk menentukan bobot KPI yang ditetapkan dalam skala nilai tertentu yang ditetapkan oleh organisasi. Penilaian untuk tiga kategori ini akan menghasilkan rambu warna merah, kuning dan hijau. Warna merah menunjukkan KPI yang diperoleh berkinerja buruk. Warna kuning berarti KPI nya berada dalam situasi peringatan, membutuhkan perhatian sesegera mungkian dari manajemen. Sedangkan KPI dengan rambu hijau berarti indikator yang ditetapkan telah sesuai dengan target yang diharapkan. Penjelasan nya dapat dilihat dalam Tabel 3.

Tabel 2. Daftar responden penelitian

\begin{tabular}{ll}
\hline \multicolumn{1}{c}{ Nama } & \multicolumn{1}{c}{ Jabatan } \\
\hline Internal & \\
Ir. Syafrullah & Plt. Dir. Prog dan Berita \\
Ir. Syafrullah & Dir. Tekhnik \\
Drs. Tribowo Kriswinarso & Dir. Umum \\
Drs. Syifak Masyhudi, MM & General Manager Pemberitaan \\
Dr. Agus Haryadi & Staff ahli Dir. berita \\
Cosmalinda Simanjuntak, BA & Manager Perencanaan Program Diklat \\
Arie Purnomo adjie, SE & Manager Berita \\
Ir. Yuni Sutrisno & Manager Tekhnik Studio \\
Eksternal & \\
Dr. Mardani Ali Sera, M.Eng & Anggota DPR RI Komisi 1 \\
Prof. Dr. Eko Prasodjo & Wamen PAN \& RB \\
\hline
\end{tabular}


Tabel 3. Jenis polarisasi data

\begin{tabular}{cccc}
\hline & Polarisasi & Status \\
\hline Maximize & Minimize & Stabilize & Merah \\
$\mathrm{X}<80 \%$ & $\mathrm{X}>120 \%$ & $\mathrm{X}<80 \%$ atau $\mathrm{X}>120 \%$ & Kuning \\
$80 \% \leq \mathrm{X}<100 \%$ & $100 \%<\mathrm{X} \leq 120 \%$ & $80 \% \leq \mathrm{X}<90 \%$ atau $120 \% \geq \mathrm{X}>110 \%$ & Hijau \\
$\mathrm{X} \geq 100 \%$ & $\mathrm{X} \leq 100 \%$ & $90 \% \leq \mathrm{X} \leq 110 \%$ & \\
\hline
\end{tabular}

Polarisasi Maximize: nilai aktual/ realisasi/ Pencapaian KPI diharapkan lebih tinggi dari target.

Indeks KPI $=$ Hasil Aktual $/$ Target X $100 \%$

Polarisasi Minimize : Nilai aktual/realisasi/ pencapaian KPI diharapkan lebih kecil dari target.

Indeks Capaian IKU $=[1+(1-$ realisasi/ target $)] \mathrm{X}$ $100 \%$

Polarisasi Stabilize : nilai aktual/ realisasi/ pencapaian KPI diharapkan dalam satu rentang target tertentu.

Kerangka pemikiran konseptual dituangkan lewat penjabaran visi dan misi TVRI kedalam Rencana strategis Direktorat Pemberitaan, target yang hendak dicapai serta inisiatif strategis yang harus dilakukan. Selanjutnya dilakukan pembobotan terhadap empat perspektif BSC untuk mengetahui perspektif mana yang memiliki kontribusi tertinggi terhadap Direktorat Pemberitaan TVRI.Sifat BSC yang koheren, saling berhubungan menghasilkan peta strategis yang digunakan sebagai peta operasi Direktorat Pemberitaan jangka panjang.Selanjutnya ditentukan KPI masingmasing perspektif dan dibobot dengan metode pairwaise comparison. Hasil pembobotan tertinggi akan menjadi indikator yang paling berpengaruh sebagai perbaikan audience share bagi Direktorat Pemberitaan. Kerangka pemikiran konseptual diterangkan dalam Gambar 2.

\section{HASIL}

Komponen-komponen Strategik (Visi-Misi) Direktorat Pemberitaan LPP-TVRI kedalam Rencana Startegik, Tujuan dan Inisiatif Strategik pada Model Pengukuran Kinerja Berbasis BSC

Hasil analisis yang dilakukan memperlihatkan penjabaran komponen-komponen strategik (visi-misi) Direktorat Pemberitan LPP-TVRI kedalam rencana strategik, tujuan dan inisiatif pada model pengukuran kinerja berbasis BSC sangat relevan dijadikan sebagai alat ukur kinerja. Berdasarkan visi TVRI, menjadi media utama penggerak pemersatu bangsa. Misinya, menyelenggarakan siaran yang menghibur, mendidik, informatif, secara netral, berimbang, sehat dan beretika. Saat diturunkan kedalam empat perspektif BSC menghasilkan rencana strategik berupa pengembangan siaran multiplatform, yang memiliki tujuan strategis yaitu meningkatkan kualitas program berita dan pada akhirnya berhasil mencapai sasaran strategiknya berupa peningkatan audience share. Model BSC yang biasa digunakan untuk lembaga proffit, pada saat diterapkan pada lembaga non-proffit seperti TVRI, megalami poenyesuaian dalam penentuan perpektif yang paling berpengaruh terhadap upaya pencapaian taraget. Pembobotan perspektifyang paling berkontribusiadalah perspektif proses bisnis internal sebesar 37,50\%.

\section{Pembobotan Perspektif BSC}

Pengolahan pembobotan terhadap empat perspektif BSC dapat dilihat pada Tabel 4. Hasil pembobotan memperlihatkan perspektif yang tertinggi adalah perspektif proses bisnis internal yaitu 37,5\%. Bobot ini menunjukkan bahwa proses bisnis internal memiliki kepentingan paling besar dibanding perspektif lainnya. Perspektif pelanggan dan stakeholders mendapatkan bobot kedua tertinggi dalam BSC Direktorat Pemberitaan, yaitu $25 \%$.

Perspektif keuangan mendapat bobot 20,83\%. TVRI sebagai lembaga non-profit tidak berorientasi mencari keuntungan. Pendanaan dari APBN menuntut TVRI harus transparan dan akuntabel dalam penggunaan dana publik melalui efisiensi dan efektifitas dan tertib administrasi keuangan. Hasil pembobotan terendah ada pada perspektif pertumbuhan dan pembelajaran sebesar $16,66 \%$. Perspektif yang menekankan pada pemberdayaan sumberdaya manusia sebagai aset organisasi. 


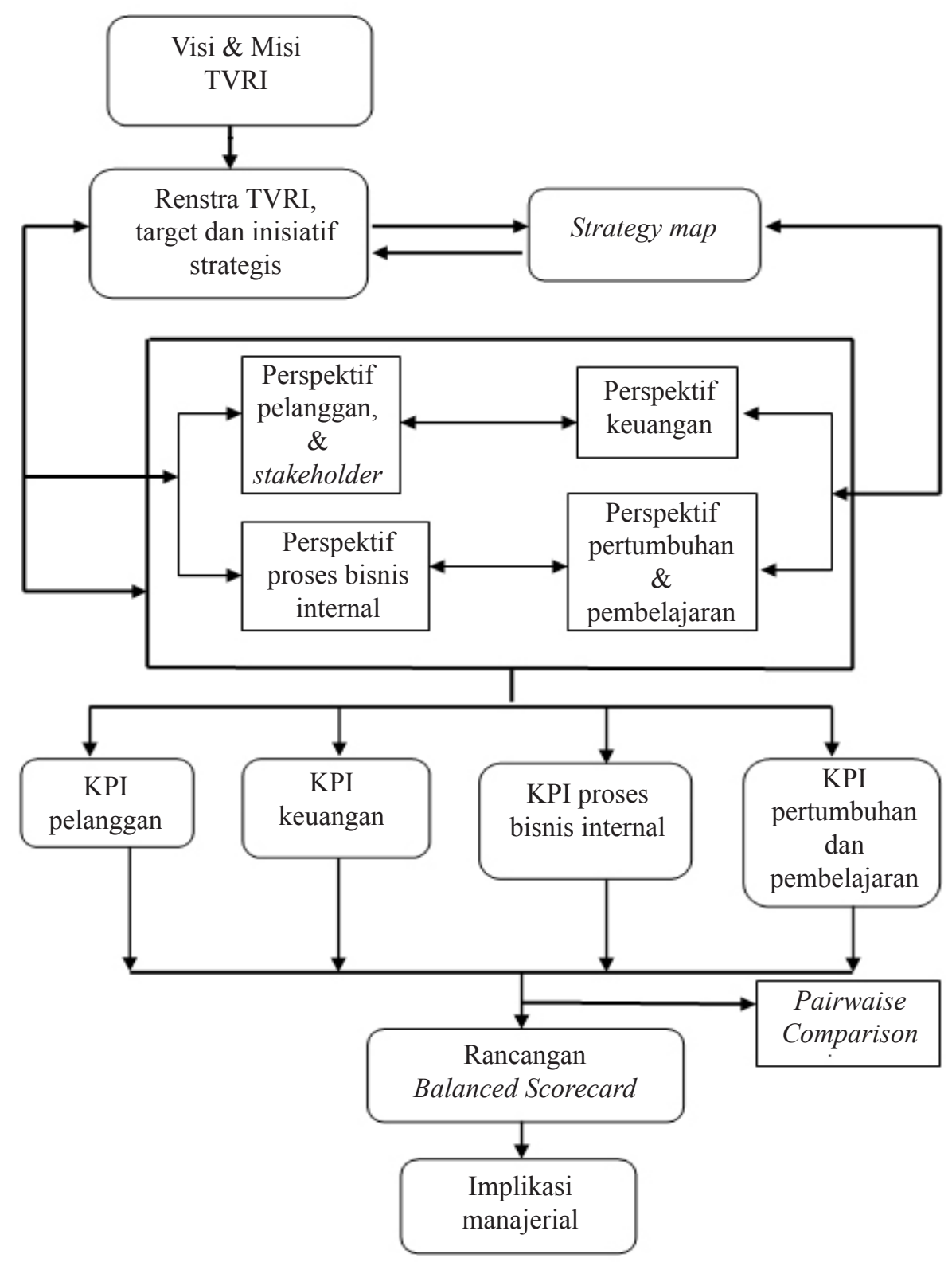

Gambar 2. Kerangka pemikiran penelitian

Tabel 4. Hasil Pembobotan 4 perspektif Balanced Scorecard Pemberitaan LPP-TVRI

\begin{tabular}{lc}
\hline \multicolumn{1}{c}{ Perspektif } & Bobot (\%) \\
\hline Pelanggan dan stakeholders & 25,00 \\
Keuangan & 20,83 \\
Proses bisnis internal & 37,50 \\
Pertumbuhan dan pembelajaran & 16,66 \\
\hline
\end{tabular}

\section{PetaStrategi(StrategyMap) Direktorat Pemberitaan LPP-TVRI}

Hubungan sebab akibat yang saling memengaruhi dalam strategy map, memperlihatkan konsistensi dalam kebijakan dan tindakan akan memengaruhi hasil dan target Direktorat Pemberitaan. Memperbaiki satu indikator sesuai tenggat waktu yang ditentukan, secara paralel memengaruhi capaian target yang lain. Hasil diskusi dari FGD dan Indepth interview didapatkan Strategy Map Direktorat Pemberitaan LPP-TVRI. Strategy Map Direktorat Pemberitaan dijelaskan dalam Gambar 3. Peta strategi dalam Gambar 3 memperlihatkan alur dari keempat perspektif BSC pada Direktorat Pemberitaan LPP-TVRI yang saling memiliki hubungan sebab-akibat. Seperti dijelaskan berikut. 


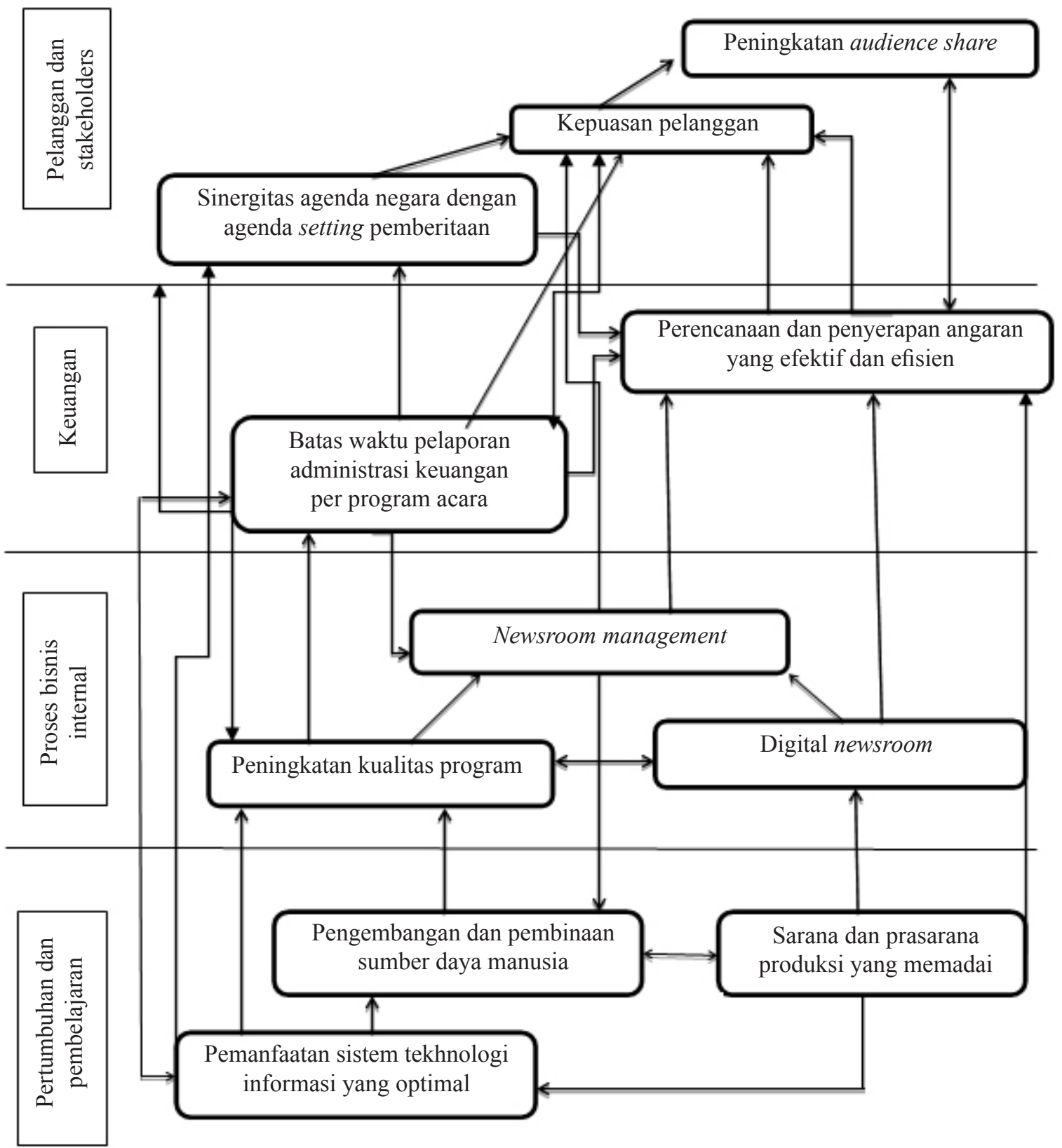

Gambar 3. Strategy map Direktorat Pemberitaan TVRI

Perspektif pembelajaran dan pertumbuhan disebut juga sebagai intangible aset dalam BSC, merupakan proses paling dasar dalam infrastruktur sumberdaya manusia. Sasaran strategis ini membutuhkan komitmen dan keterlibatan seluruh lini organisasi untuk mewujudkan tujuan organisasi.Organisasi menempatkan pegawai sebagai aset sehingga pengembangan dan pembinaan sumberdaya manusia menempati posisi berimbang dengan upaya pemenuhan sarana dan prasarana produksi yang memadai.tingkat keterdidikan, keahlian, dan keterampilan SDM di bidang profesi menjadi penting guna menggerakkan roda organisasi dan mengelola operasional siaran.Kedua sasaran strategis ini saling mengisi untuk menghasilkan kinerja terbaik lembaga disamping optimalisasi pemanfaatan sistem tekhnologi informasi.Ketersediaan jaringan internet misalnya berpengaruh positif terhadap kecepatan Direktorat Pemberitaan dalam mengumpulkan berita yang dikirim secara streaming dari berbagai lokasi peristiwa, termasuk berita yang dikirim oleh stasiun daerah maupun kontributor TVRI.

Perspektif proses bisnis internal, disebut juga sebagai pusat inovasi organisasi. Upaya melakukan transformasi dengan melakukan managemen redaksi yang lebih baik, termasuk penataan standar prosedur operasional yang baku, mempercepat target perbaikan yang diharapkan. Konsistensi menjaga editorial policy 
pemberitaan akan memudahkan langkah organisasi menjaga proses produksi berita hingga penyiaran bias dari kepentingan. Sebagai TV Publik yang diamanatkan harus menjaga netralitas, independensi dan bersifat imparsial, harus lepas dari kepentingan kelompok manapun termasuk tekanan politik. Oleh karena itu, keberadaan stasiun penyiaran publik yang independen dan netral merupakan harus terus didorong untuk mempercepat proses demokratisasi. Peningkatan kualitas program acara menjadi keharusan didukung oleh format digital yang memberikan keleluasan pada ide-ide kreatif menemukan bentuk. Perkembangan teknologi produksi dan penyiaran televisi saat ini didukung tenaga-tenaga andal dengan keahlian dan keterampilan prima sesuai profesinya, diharapkan bisa memicu lahirnya tayangan acara berkualitas sehingga mampu mendorong peningkatan audience share TVRI, khususnya Direktorat Pemberitaan.

Pada perspektif keuangan, memastikan serapan anggaran sesuai dengan target tahunan yang dibuat secara efektif dan efisien harus terus diwujudkan.Posisi TVRI sebagai lembaga negara yang harus tunduk pada aturan penggunaan keuangan berdasarkan ketetapan kementrian keuangan, disatu sisi harus disikapi secara bijaksana, agar dinamika dunia penyiaran yang sangat dinamis dan lentur bisa sejalan dengan aturan birokrasi. Prinsip pertanggung jawaban keuangan yang transparan berdasarkan prinsip good governance, menjadi representasi akuntabilitas Direktorat Pemberitaan yang dapat dilihat salah satunya lewat kualitas tayangan di layar.Kepuasan pelanggan menjadi kata kunci bagi pelayanan Direktorat Pemberitaan.Peningkatan hubungan kerjasama yang baik dengan pelanggan untuk meningkatkan kepuasan dan kesetiaan pemirsa harus terus diupayakan. Selain itu perbaikan juga menjadi pertanggung jawaban kepada pemerintah selaku stakeholder.

\section{Faktor-faktor Penentu KPI}

Hasil FGD yang dilakukan dan Indepth interview, memetakan sejumlah KPI yang harus dilaksanakan secara konsekuen oleh manajemen.

\section{Perspektif Pelanggan dan stakeholders (C)}

\section{Peningkatan audience share}

\section{Persentase audience share existing}

Berdasarkan Roadmap TVRI 2012-2022 LPP-TVRI, dinyatakan TVRI adalah TV berita dan menargetkan pada tahun 2018, audience share TVRI bisa mencapai angka 7\%. FGD yang diadakan dalam kerangka penentuan KPI dan target yang hendak dicapai Direktorat Pemberitaan, mencoba merumuskan kemampuan capaian TVRI pada tahun 2014 dalam rangka meningkatkan audience share diangka $2 \%$. Penetapan angka ini saling berkejaran dengan audience share Metro TV pada minggu ke-26 tahun 2013 sebesar $2 \%$. Akan tetapi, pembintangan mata anggaran belanja modal TVRI oleh komisi I DPR-RI pada awal tahun 2014 membuat sejumlah rencana bergeser dan target -target yang telah disusun diawal tahun menjadi meleset. Salah satunya adalah keinginan meningkatkan audience share di penghujung tahun 2014.

\section{Kepuasan pelanggan}

\section{Mengadakan program citizen journalism}

Perubahan pada dunia jurnalistik ditandai dengan perubahan prilaku dan gaya reportase yang berkembang. Jurnalisme perang, jurnalisme sipil, jurnalisme investigasi dan trend terbaru saat ini adalah jurnalisme warga (citizen journalism). Lahirnya jurnalisme gaya ini berawal dari kesadaran media bahwa, komunikasi yang dijalin antara mereka dan pemirsanya seharusnya juga melibatkan partisipasi warga.

Direktorat Pemberitaan TVRI juga merespon desakan perubahan tersebut dengan cepat. Menyediakan slot waktu 30 menit setiap harinya untuk citizen journalism ditetapkan menjadi bagian dari KPI pemberitaan.

\section{Mendirikan komunitas pecinta TVRI}

Komunitas pecinta TVRI saat ini sudah berdiri di 8 propinsi yaitu, propinsi Yogyakarta, Sumatera Barat, Kalimantan Selatan, Bali, Bengkulu, Nusa Tenggara barat dan Sulawesi Selatan. Anggota komunitas terdiri atas tokoh-tokoh masyarakat, tokoh adat,seniman, budayawan hingga generasi muda setempat. Diskusi terbuka diadakan secara berkala dengan difasilitasi oleh TVRI daerah untuk kemudian dirumuskan menjadi sebuah kebijakan yang muncul dalam bentuk program acara di tingkat pusat. 


\section{Sinergitas agenda negara dengan agenda pemberitaan}

\section{Programming obligation}

Sebagai TV Publik, TVRI memiliki kewajiban menyiarkan program-program acara yang kontennya berisikan materi yang sifatnya sosialisasi, pembangunan, menangkap suara kalangan minoritas. Tayangan yang secara struktur tidak akan menarik bagi TV Swasta karena tidak memiliki nilai jual bagi pemasang iklan.

Program siaran internasional

Menurut PP 11/2005, pasal 4, TVRI dalam menjalankan kegiatan operasional bertujuan untuk menyajikan program siaran yang mendorong terwujudnya sikap mental masyarakat yang beriman dan bertakwa, cerdas, memperkukuh integrasi nasional dalam rangka membangun masyarakat mandiri, demokratis, adil dan sejahtera, serta menjaga citra positif bangsa

\section{Perspektif Keuangan (F)}

\section{Perencanaan dan penyerapan anggaran yang efektif dan effisien}

Tingkat realisasi penyerapan anggaran

Target realisasi penyerapan anggaran untuk Direktorat Pemberitaan selama tahun 2014 adalah 90\%. Sementara tingkat realisasi penyerapan anggaran pada tahun 2014 adalah $80,52 \%$.

\section{Batas waktu pelaporan administrasi keuangan per- program acara}

Jumlah hari pelaporan administrasi keuangan

Proses produksi pemberitaan menggunakan pendanaan dari APBN. Untuk menjaga tertib administrasi keuangan maka semua unit manager yang bertanggung jawab dalam proses pengurusan administrasi keuangan juga dituntut memperbaiki kinerja mereka.

\section{Perspektif proses bisnis internal (O)}

\section{Newsroom management}

Managemen redaksi mutlak diperlukan bagi sebuah media penyiaran, mengingat pekerjaan penyiaran adalah kerja tim yang harus solid. Jika salah satu mata rantai keredaksian terlambat, akibatnya produksi media secara keseluruhan akan ikut terlambat. Reporter, kameramen, audioman, editor dan redaksi memiliki fungsi dan tanggung jawabnya masing-masing.

Jumlah kontributor daerah

Komposisi pegawai TVRI saat ini belum terdistribusi secara merata. Satuan kerja administrasi mendominasi jumlah karyawan. Jalan keluar yang kemudian dipilih adalah dengan memberdayakan kontributor di daerah untuk melakukan peliputan berita. Koordinator liputan kontributor daerah dapat memerintahkan kontributor di seluruh Indonesia untuk melakukan peliputan berita yang sifatnya mendesak dan dinilai penting.

\section{Digital newsroom}

Membangun digital newsroom

Amanat yang di berikan kepada TVRI sebagai lembaga penyiaran pionir dengan sistem digital, mengharuskan TVRI juga menyesuaikan peralatan dengan tuntutan, membangun redaksi dengan konsep digital yang terintegrasi dengan studio penyiaran menjadi target yang hendak dilaksanakan pada tahun 2014. Namun hingga akhir tahun 2014, target ini tidak tercapai karena hingga akhir bulan Juli, mata anggaran belanja modal TVRI masih dibintangi oleh Komisi 1 DPR-RI.

Jumlah digital studio

Upaya memperbaiki on air look dengan melakukan pembangunan studio digital sudah berhasil dilakukan oleh TVRI untuk studio 4 Pemberitaan. Meski meleset dari target semula yang hendak dilaksanakan pada studio 6 TVRI yang selama ini digunakan untuk aktivitas penyiaran berita, buletin berita dan studio dialog. 


\section{Peningkatan kualitas program}

Perbaikan program pada prime time

Dalam dunia broadcasting, pembagian waktu tayang dinamai menjadi beberapa bagian yang didasarkan pada banyaknya total penonton yang tersedia, yaitu Fringe 1-3, Shoulder 1-2 dan Prime Time. Di TVRI, Sebelumnya konsekuensi dari perbedaan jam tayang menyebabkan prioritas penempatan mata acara dalam pola siaran dan perbedaan biaya produksi siaran.

Persentase konten siaran informasi

Pedoman Roadmap TVRI, menyebutkan penggolongan acara siaran yang dianut TVRI, seperti dalam gambar 13 sebagai berikut: Siaran pemberitaan dan penerangan (news and information), Siaran pendidikan (education), Siaran kebudayaan (cultural), Siaran hiburan (entertainment) dan siaran lain-lain (miscellaneous). Dalam target yang disusun untuk 2014 perubahan yang dilakukan adalah merubah komposisi tipe program menjadi 55\% informasi, 28,6\% edukasi dan 16,4\% hiburan. Genre besar tersebut kemudian dipecah lagi news-bulletin \& current affairs, information-magazine \& documentary, dan edutainment-adventure \& kids edutainment.

Persentase konten siaran edukasi

Persentase siaran edukasi sama halnya dengan siaran informasi juga mengalami penyesuaian. Dibutuhkan lebih banyak slot acara untuk melakukan sosialisasi dan dialog publik terkait aturan baru tentang Pemilu. Siaran edukasi dari target $28,6 \%$ naik menjadi $30 \%$ komposisi acara nya.

\section{Perspektif Pertumbuhan dan pembelajaran (G)}

\section{Pengembangan dan pembinaan sumber daya manusia}

Jumlah pelaksanaan pembinaan dan ketrampilan pegawai

TVRI harus merencanakan penerimaan pegawai secara cermat untuk memenuhi kebutuhan tenaga kerja profesional di bidang produksi dan penyiaran. Tenaga kerja yang ada. saat ini sudah kurang memadai, sebab banyaknya jumlah karyawan yang pensiun dalam lima tahun terakhir, sementara rekrutmen karyawan baru masih dilakukan dengan sangat terbatas.

\section{Pemanfaatan sistem tekhnologi informasi yang optimal}

Jumlah PC yang terhubung dalam jaringan

Persentase jumlah PC yang terhubung dalam jaringan sudah $100 \%$. Meski telah mencapai target, tetapi dari sisi jumlah PC masih dibutuhkan penambahan, mengingat penambahan karyawan baru tidak berbanding lurus dengan penambahan komputer. Dari 80 unit PC yang dimiliki semua nya bisa terakses Wi-Fi.

Jumlah downtime yang terjadi

DarisisijumlahunitPCyangtersambung denganinternet karena adanya jaringan Wi-fi sudah memuaskan, tetapi dalam pengelolaan server, belum mencapai target yang diinginkan. Jumlah downtime belum berhasil ditekan. Sepanjang tahun 2014 masih terjadi downtime hingga 5 kali yang menyebabkan terjadi nya kendala dalam berproduksi.

\section{Sarana dan prasarana produksi yang memadai}

Persentase kecukupan sarana produksi

Ketersediaan sarana dan prasarana pendukung produksi untuk Direktorat Pemberitaan untuk peralatan penunjang produksi masih jauh dari standar ideal. Target yang hendak dicapai kondisi sarana dan prasarana peralatan yang memadai diangka $90 \%$, realisasi nya masih di bawah harapan, yaitu $83,57 \%$.

\section{Simulasi rancangan Pengukuran kinerja Direktorat Pemberitaan LPP-TVRI}

Simulasi rancangan pengukuran kinerja Direktorat Pemberitaan LPP-TVRI dengan metode BSC dan menggunakan standar pengelolaan kinerja Kementrian Keuangan 2010, memperlihatkan kemampuan Direktorat Pemberitaan TVRI mencapai target yang telah ditetapkan lembaga masih jauh dari harapan. Semua indikator yang dijadikan sebagai aksi perubahan memperoleh rambu merah. 
Pada perspektif pelanggan terdapat empat KPI yang mendapatkan nilai merah. Meski TVRI selalu menggunakan argumentasi bahwa rating tidak diperlukan bagi televisi publik, TVRI tetap membutuhkan sebuah parameter untuk mengetahui posisi TVRI dalam industri penyiaran tanah air.

Pada perspektif keuangan, terdapat dua KPI yang berwarna merah. Akibat performa yang buruk mengakibatkan sejumlah program acara tidak dapat diproduksi. Tumpang tindihnya penanggung jawab adminstrasi keuangan untuk program pemberitaan mendesak dicarikan jalan keluarnya, seperti relokasi karyawan.

Pada perspektif proses bisnis internal, terdapat tujuh KPI yang berwarna merah. Rapat produksi diadakan satu kali dalam sehari, dengan tujuan menentukan topic of the day (topik hari ini). Rapat redaksi menjadi penting bagi Direktorat Pemberitaan, karena melalui rapat redaksi juga dapat dirumuskan agenda setting yang hendak diperankan oleh LPP-TVRI melalui berita yang disampaikan.

Mewujudkan digital newsroom sebagai bank data berita dan digital newsroom juga akan menjawab tantangan convergence journalism (siaran multiplatform) yang segera harus dihadapi TVRI. Pada perspektif proses bisnis internal, terdapat tujuh KPI yang berwarna merah. Rapat produksi diadakan satu kali dalam sehari, dengan tujuan menentukan topic of the day (topik hari ini). Rapat redaksi menjadi penting bagi Direktorat Pemberitaan, karena melalui rapat redaksi juga dapat dirumuskan agenda setting yang hendak diperankan oleh LPP-TVRI melalui berita yang disampaikan.

Mewujudkan digital newsroom sebagai bank data berita dan digital newsroom juga akan menjawab tantangan convergence journalism (siaran multiplatform) yang segera harus dihadapi TVRI.

Untuk perspektif pertumbuhan dan pembelajaran terdapat empat KPI yang berwarna merah.Berdasarkan diskusi dengan pihak Pusdiklat, diketahui selama ini tidak pernah ada usulan apapun dari Direktorat Pemberitaan TVRI terkait diklat profesi jenis apa yang dibutuhkan dan mendesak diadakan oleh Balaidiklat. Konsekuensinya bagian Diklat melaksanakan pelatihan profesi karyawan berdasarkan skedul yang mereka buat sendiri, tanpa melibatkan Pemberitaan sebagai end user. Sebaliknya, downtime yang terjadi selama tahun 2014, meleset dari target, yang seharusnya tiga kali, justru bertambah menjadi lima kali. Situasi ini tentu tidak baik bagi performa Direktorat Pemberitaan mengingat upaya menuju digitalisasi membutuhkan kelayakan server yang mendukung. Untuk KPI Jumlah PC yang tergabung dalam jaringan juga belum memadai di dukung ketersediaan Wi-Fi.

\section{Implikasi Manajerial}

Pembahasan pengukurankinerjaDirektoratPemberitaan TVRI menghasilkan beberapa informasi penting yang dapat dijadikan sebagai dasar pengukuran kinerja lembaga ini kedepan, mengingat TVRI selama ini belum memiliki alat ukur kinerja lembaga secara keseluruhan. TVRI memerlukan alat ukur yang bisa diterapkan dan membutuhkan manajemen strategik bagi manajemen untuk menentukan prioritas organisasi.

\section{KESIMPULAN DAN SARAN}

\section{Kesimpulan}

Hasil penjabaran komponen strategik Direktorat Pemberitaan LPP-TVRI kedalam rencana strategis, tujuan dan inisiatif melalui empat perspektif BSC menghasilkan output dan outcome yang terukur, sekaligus bisa dievaluasi oleh jajaran top manajemen. Angka yang dihasilkan akan memperlihatkan seberapa kemampuan manajemen merealisasikan target yang telah ditetapkan sepanjang tahun.

Alur keempat perspektif BSC yang menghasilkan strategy map saat dilakukan pembobotan dengan metode pairwaise comparison menunjukkan kontribusi tertinggi dihasilkan oleh perspektif proses bisnis internal. Fokus perbaikan pada perspektif ini, akan memperlihatkan perbaikan yang signifikan. Selain itu prinsip hubungan sebab akibat dalam strategy map, akan memperlihatkan setiap alur saling terhubung satu dengan yang lain. Memperbaiki satu perspektif dan faktor-faktor turunannya akan berpengaruh terhadap perbaikan perspektif yang lain.

Upaya Direktorat Pemberitaan meningkatkan audience share sebagai bentuk pertanggungjawaban penggunaan dana publik lewatAPBN, dilakukan dengan menentukan KPI yang harus dilaksanakan. Hasil pembobotan KPI memperlihatkan tiga KPI dengan bobot tertinggi pada perspektif proses bisnis internal. Ketiga KPI ini 
adalah, production meeting 20,5\%. Membangun digital newsroom 19,23\% dan jumlah digital studio 15,38\%.

Simulasi rancangan penilaian kinerja atas Direktorat Pemberitaan LPP-TVRI, yang diturunkan dari metode BSC dan membuat alur hubungan sebab akibat lewat Strategy Map, menghasilkan sejumlah KPI yang harus dijalankan oleh manajemen TVRI. Pembobotan terhadap KPI yang diukur melalui pencapaian target diakhir tahun menghasilkan rambu merah untuk semua indikator. Rambu merah menunjukkan lemahnya kinerja Direktorat Pemberitaan TVRI.

\section{Saran}

Pelaksanaan manajemen strategik BSC pada organisasi LPP-TVRI Direktorat Pemberitaan pada akhirnya butuhkan komitmen dan keseriusan manajemen puncak.Target perbaikan layar melalui peningkatan audience share dapat di optimalkan jika kesamaan persepsi atas pemanfaatan BSC dapat di sosialisasikan dengan baik oleh manajemen puncak hinga ke lini paling bawah.Selain itu manajemen harus memastikan semua indikator yang telah ditetapkan sebagai prioritas dilaksanakan dengan komitmen tinggi. Penelitian yang penulis lakukan hanya sebatas simulasi pengukuran kinerja di lingkungan Direktorat Pemberitaan, masih diperlukan penelitian lanjutan untuk semua Direktorat di organisasi TVRI secara keseluruhan.

\section{DAFTAR PUSTAKA}

Anthoula K, Alexandros H. 2011. Designing a Balanced Scorecard for the evaluation of a local authority organization. European Research Studies 14(2):65-80.

Armando A. 2011. Televisi Jakarta di atas Indonesia. Jakarta: PT Mizan Publika.

Body AL, Keengwe J, Mukankusi L. 2008. E-government service delivery performance: an adaptation of the Balanced Scorecard to the public sector. Journal of Electronic Commerce in Organization 6(2):11-28.

Koumpourus Y. 2012. Balanced scorecard: application in the general Pacardian hospital of Tripolis, Greece. International Journal of Health Care Quality Assurance 26(4):286-307.

Lang, Sandra S. 2004. Balanced Scorecard and government entities. The CPA journal 74(6):4852.

Mark A. 2005. Public service broadcasting. Fiscal Studies Journal 26(3):281-299

Mei LI, Jiang WU. 2013. The reconstruction of the balanced scorecard in Chinese local governments: correction model based on service oriented government strategic goals. Canadian Social Science 9(5):156-161. 